\title{
Holistic Work Engagement pada Tenaga Kesehatan di Kota Jakarta Barat: Pengaruh Digital Quotient, Authentic Leadership, dan Perceived Organizational Support selama Covid-19 (Holistic Work Engagement on Health Care Worker in West Jakarta: The Effect of Digital Quotient, Authentic Leadership and Perceived Organizational Support During the Covid-19)
}

Adellia Anggun Trisnawati ${ }^{1}$, Kerin Sianto ${ }^{2}$, Lady Aldli Seansyah ${ }^{3 *}$, Nopriadi Saputra ${ }^{4}$ Jurusan Manajemen, Universitas Bina Nusantara, Jakarta Barat ${ }^{1234}$ adellia.trisnawati@binus.ac.id ${ }^{1}$, kerin.sianto@binus.ac.id ${ }^{2}$, lady.seansyah@binus.ac.id ${ }^{3 *}$, nopriadi.saputra@binus.ac.id ${ }^{4}$

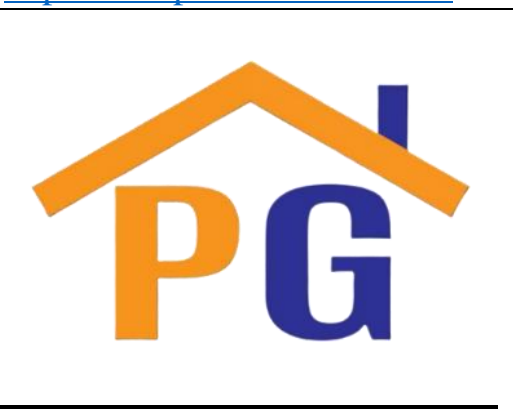

Riwayat Artikel

Diterima pada 25 June 2021

Revisi 1 pada 2 July 2021

Revisi 2 pada 8 July 2021

Disetujui pada 9 July 2021

\begin{abstract}
Purpose: This study aimed to determine the impact of digital quotient, authentic leadership, and perceived organizational support on work engagement of employees who work in the health industry during this COVID-19 in West Jakarta.
\end{abstract}

Research methodology: The methods in this research were quantitative and survey. We obtained primary data through the questionnaire distribution with 391 respondents of health care workers who work in West Jakarta. This study used multiple regression techniques as the data analysis technique.

Results: The study results indicate that digital quotient, authentic leadership, and perceived organizational support influence work engagement.

Limitations: Only digital quotient, authentic leadership, perceived organizational support, work engagement variables, and health care workers in West Jakarta were assessed in this research.

Contribution: This study shows the level of work engagement, digital quotient, authentic leadership, perceived organizational support and how digital quotient, authentic leadership, and perceived organizational support affect work engagement. Employers or organizations can use this research to improve their employees' work engagement by noticing their employee's level of digital quotient and implementing authentic leadership and perceived organizational support.

Keywords: Work Engagement, Digital Quotient, Authentic Leadership, Perceived Organizational Support.

How to cite: Trisnawati, A, A., Sianto, K., Seansyah, L. A., \& Saputra, N. (2021). Holistic Work Engagement pada Tenaga Kesehatan di Kota Jakarta Barat: Pengaruh Digital Quotient, Authentic Leadership, dan Perceived Organizational Support selama Covid-19. Jurnal Akuntansi, Keuangan, dan Manajemen, 2(4), 255-278.

\section{Pendahuluan}

Dunia saat ini sedang berada di bawah tekanan dari pandemic COVID-19. World Health Organization (WHO) menstrukturkan upaya untuk mengendalikan implikasi dan mengemukakan COVID-19 sebagai global pandemic pada 11 Maret 2020. COVID-19 ditularkan lewat droplet atau rintik-rintik cairan lewat mulut ataupun hidung yang menular ketika orang yang terpapar virus bersin ataupun batuk. 
(KawalCovid19, 2020). Salah satu daerah di Jakarta dengan kasus COVID-19 yang cukup tinggi yaitu Kota Jakarta Barat dengan jumlah 2.466 yang tersebar di 11 kelurahan (Beritasatu, 2021). Pada awal tahun 2021 kasus COVID-19 di wilayah Jakarta Barat bisa bertambah mencapai 400 kasus per hari, ujar Walikota Jakarta Barat Uus Kuswanto (Kompas, 2021). Akibatnya, beberapa Rumah Sakit (RS) rujukan COVID-19 di Jakarta Barat mulai tidak tersedia lagi. Meskipun begitu, Walikota Jakarta Barat Uus Kuswanto percaya bahwa Rumah Sakit (RS) masih bisa mengakomodasi untuk perawatan pasien COVID-19 (Merdeka, 2021). Seiring meningkatnya jumlah kasus COVID-19, terdapat beberapa tenaga kesehatan yang mulai gugur akibat pandemi COVID-19 di Indonesia. Berdasarkan pencatatan lapor COVID-19 sampai 16 Maret 2021 total ada 843 tenaga kesehatan yang telah gugur akibat COVID-19 dari 29 provinsi di Indonesia (LaporCovid19, 2021).

COVID-19 membawa pengaruh ke berbagai sektor seperti transportasi hingga pelayanan publik termasuk industri kesehatan, ekonomi dan pariwisata. Menurut dr Cut Putri Arianie, MHKes sebagai Direktur Pencegahan dan Pengendalian Penyakit Tidak Menular menyatakan penanggulangan COVID19 akan berhasil jika semua lintas program yang terkait kompak (Antaranews, 2020). Dalam menangani COVID-19 rumah sakit memiliki peran penting bagi masyarakat sebagai tempat penyedia jasa pelayanan kesehatan. Menurut Keputusan Menteri Kesehatan Republik Indonesia No.340/MENKES/PER/III/2010 Rumah Sakit merupakan sebuah institusi pelayanan kesehatan yang menyediakan pelayanan kesehatan bagi perorangan dan pelayanan rawat inap, rawat jalan serta gawat darurat. Tenaga kesehatan juga berperan penting sebagai harapan utama dalam menangani COVID-19 (Merdeka, 2020). Ketua Umum Persatuan Perawat Nasional Indonesia (PPNI) Harif Fadhillah juga mengatakan bahwa peran perawat saat pandemi masuk sebagai salah satu inti dari sistem pertahanan dalam kesehatan sesuai dengan pernyataan WHO tentang perawat berada di garda depan dalam menangani pasien melawan COVID-19 di seluruh dunia (PPNI, 2021).

Smulders (2006) menyatakan bahwa pekerjaan selain seorang entrepreneur dan seorang guru yang memiliki tuntutan work engagement yang tinggi yaitu seorang perawat. Karena tenaga kesehatan harus mempunyai sikap positif dalam work engagement untuk dapat selalu memberikan pelayanan berkualitas meski dituntut berbagai macam tekanan dalam pekerjaan. Iswanto dan Agustina (2016) mengatakan bahwa banyaknya work engagement karyawan di suatu organisasi mengakibatkan organisasi semakin maju dan berkembang karena semakin banyak manfaat yang diterima. Seiring dengan berkembangnya era globalisasi, kita diharuskan untuk dapat menyesuaikan diri dan memahami perusahan yang telah terjadi di lingkungan kita saat ini salah satunya yaitu kecerdasan digital atau digital quotient. Menurut Bartlett-Bragg (2017) terdapat berbagai penelitian yang sedang dilakukan terhadap transformasi digital organisasi dan model bisnis mereka dengan McKinsey yang mengacu pada digital quotient organisasi berdasarkan kematangan digital yang dievaluasi dengan cara mengukur praktik terhadap strategi digital, kapabilitas dan budaya. Kecerdasan digital atau digital quotient didefinisikan sebagai sekumpulan kompetensi teknis, kognitif, metakognitif dan sosio-emosional yang didasarkan pada nilai moral agar individu dapat memanfaatkan peluang saat menghadapi tantangan (Fitaloka et al., 2020). Tantangan dalam menghadapi kehidupan digital tersebut tidak hanya berlaku kepada pemimpin organisasi atau perusahaan saja, namun kita juga diharapkan untuk dapat menyesuaikan diri dan menghadapinya. Dengan teknologi digital yang telah tertanam di dalam setiap aspek pribadi dan kehidupan professional, pemimpin harus berkembang dan meningkatkan digital quotient (Sahyaja dan Rao, 2018). Pemimpin yang sukses akan memiliki dan mempraktikkan kualitas digital quotient untuk dapat beradaptasi dan berubah dengan cara memasukkan kemampuan digital ke dalam organisasi (Sahyaja \& Rao, 2018).

Begitu halnya dalam berorganisasi, setiap organisasi akan berfokus dalam pengelolaan tenaga kerja yang efektif agar kualitas kerja dapat meningkat terutama dalam pelayanan kesehatan. Dalam menjalankannya kepemimpinan sangat dibutuhkan dalam organisasi untuk mengelola sumber daya manusia. Hal tersebut dikarenakan pendorong utama yang efektif untuk membentuk sikap dan perilaku kerja karyawan adalah kepemimpinan (Tims et al., 2011). Gaya kepemimpinan yang positif berkaitan dengan work engagement. Salah satu kepemimpinan yang diakui sebagai pendekatan kepemimpinan positif adalah authentic leadership (Oh, 2018). Pendapat tersebut juga didukung oleh Joo dan Jo (2017) yang menjelaskan beberapa hal penting dari authentic leadership seperti emosi yang positif, kepercayaan diri, harapan, dan tujuan yang terarah akan memberikan motivasi kepada bawahan untuk 
memperluas pandangan kerja mereka dan membawa pengaruh positif untuk organisasi. Hasil penelitian Boshoff (2018) juga membuktikan bahwa terdapat pengaruh positif antara authentic leadership dengan work engagement.

Dalam penerapannya ke dalam organisasi dibutuhkan peran perceived organizational support untuk mendukungnya. Perceived organizational support ialah suatu bentuk dukungan sosial yang termasuk dalam job resources yang dapat mempengaruhi work engagement. Menurut hasil penelitian Stefanidis dan Strogilos (2021) terdapat pengaruh positif antara perceived organizational support terhadap work engagement. Saat aryawan mendapatkan dukungan yang positif dari perusahaan makai a akan menerima dukungan tersebut secara positif, begitu juga sebaliknya. Sama halnya dengan pendapat lain yang mengatakan bahwa karyawan akan terdorong untuk merasa terikat terhadap pekerjaan yang mereka lakukan ketika karyawan merasakan adanya dukungan dari organisasi seperti evaluasi kognitif dan emosional (Murthy, 2017).

\section{Tinjauan Pustaka dan Pengembangan Hipotesis}

Pada bagian ini akan membahas lebih jauh mengenai work engagement, digital quotient, authentic leadership, perceived organizational support dari konsep dan penelitian terdahulu.

\subsection{Work Engagement}

Work engagement dan employee engagement merupakan istilah yang bisa digunakan secara bergantian (Schaufeli, 2013). Penjelasan lebih spesifik oleh Schaufeli (2013) yaitu dimana work engagement menerangkan tentang hubungan yang terjadi antara karyawan dengan pekerjaan yang dilakukannya, sedangkan employee engagement menerangkan tentang hubungan yang terjadi antara karyawan dengan organisasi tempatnya bekerja. Sama dengan Mujiasih dan Ratnaningsih (2012) yang mengatakan work engagement didalam pekerjaan diartikan sebagai anggota organisasi yang mengekspresikan dirinya selama bekerja baik secara kognitif, fisik dan emosional untuk melaksanakan peran kerjanya. Menurut (Simon, 2011) terdapat factor-faktor yang dapat mempengaruhi work engagement adalah lingkungan kerja, dukungan sosial, motivasi, psychological well-being karyawan dan pengambilan keputusan. Macey et al (2009) menyatakan bahwa ketekunan, proaktif, perluasan peran, dan kemampuan beradaptasi merupakan semua fitur dari perilaku keterlibatan yang secara agregat, berkonotasi kinerja di atas dan di luar ekspektasi biasa atau normal. Yang paling penting merupakan keterlibatan bukan hanya lebih banyak kinerja, tetapi kinerja yang gigih, mudah beradaptasi, dimulai sendiri, dan melibatkan pengambilan tanggung jawab baru. Konsep holistic work engagement oleh Saputra et al. (2018) keterikatan kerja adalah kondisi diri yang utuh antara fisik, intelektual, emosional dan spiritual dalam bekerja. Konsep holistic work engagement menurut Saputra et al. (2018) direfleksikan menjadi empat dimensi, yaitu terlekat secara fisik (physically engaged), terlekat secara intelektual (intellectually engaged), terlekat secara emosional (emotionally engaged), dan terlekat secara spiritual (spiritually engaged).

Dari penelitian terdahulu telah membuktikan bahwa digital intelligence quotient memberi kontribusi teoritis untuk meningkatkan employee understanding (Na-Nan et al., 2019). Dari studi empiris lainnya juga dapat dibuktikan bahwa terdapat hubungan positif antara variabel authentic leadership dengan work engagement menurut (Plessis dan Boshoff, 2018) serta terdapat pengaruh antara perceived organizational support terhadap work engagement (Stefanidis \& Strogilos, 2021).

\subsection{Digital Quotient}

Digital quotient merupakan cara untuk berpikir baru pada era digital. Dengan pengertian tersebut dapat dipahami bahwa ini tentang bagaimana orang-orang memulai untuk berpikir dengan cara berbeda dengan mencoba menyesuaikan dirinya dengan perluasan lingkungan digital. Penelitian mencoba mendemonstrasikan bahwa kecerdasan digital dapat berbeda dari yang terkait, seperti literasi, kompetensi digital dan keterampilan digital, yang mana sebagian besar dapat diperoleh melalui program pembelajaran, pendidikan, pengalaman dan pelatihan (Hakanen et al., 2019). 
Menurut Na-Nan et al. (2019) mengatakan bahwa digital quotient terdapat delapan dimensi, yaitu digital identity, digital safety, digital use, digital communication, digital security, digital rights, digital emotional intelligence dan digital literacy. Digital quotient diartikan sebagai satu set komprehensif teknis, sosio-emosional, kognitif dan kompetensi metakognitif yang didasari pada nilai moral universal mendasar dan yang mana memungkinkan individu untuk dapat selalu menghadapi tantangan dan memanfaatkan suatu peluang yang ada (Samsudin et al., 2020). Lee et al. (2019) menyatakan bahwa kecerdasan digital adalah salah satu solusi yang memungkinkan individu untuk dapat menghadapi sebuah tantangan agar dapat beradaptasi dengan tuntutan yang ada dalam kehidupan digital.

Dari penelitian terdahulu telah membuktikan bahwa digital intelligence quotient memberi kontribusi teoritis untuk meningkatkan employee understanding (Na-Nan et al., 2019). Hal tersebut didukung juga oleh penelitian Fitaloka et al. (2020) dengan hasil terdapat pengaruh positif antara digital quotient dengan work engagement.

H1: Terdapat pengaruh yang signifikan digital quotient (X1) terhadap work engagement (Y) saat pandemic COVID-19 pada tenaga kesehatan di kota Jakarta Barat.

\subsection{Authentic Leadership}

Authentic leadership merupakan gaya kepemimpinan yang populer di beberapa tahun terakhir karena merupakan salah satu solusi berpotensi dalam menghadapi tantangan kepemimpinan yang modern (Caza \& Jackson, 2011). Seorang pemimpin harus memiliki bakat dan juga bisa melakukan penyesuaian jika terjadinya perubahan karena kepemimpinan ini diyakini lebih efektif dan dapat memimpin dengan tujuan dan nilai yang lebih siap (Alavi et al, 2018). Menurut Walumbwa et al. (2008) dalam membuat suatu konsep authentic leadership sebagai pola dari perilaku pemimpin yang berkembang didasari pada karakter psikologis positif pemimpin dan etika pemimpin yang kuat.

Authentic leadership yang diukur oleh Datta (2015) terdapat 12 dimensi yang dibagi menjadi dimensi keefektifan manajerial (managerial effectiveness), yaitu kinerja organisasional, peningkatan kualitas kehidupan kerja, kepuasan atas kebutuhan dan harapan anggota, pengembangan anggota, kontribusi manajer terhadap ketidakhadiran anggota, kontribusi manajer terhadap proses pengelompokkan unit atau organisasinya, kontribusi manajer terhadap ketidakpuasan dan permusuhan/kebencian anggota, sejauh mana manajer memiliki karir yang sukses dan dimensi kepemimpinan (leadership effectiveness), yaitu menghargai pemimpin, komitmen untuk menjalankan perintah pimpinan, membuat keputusan, dan mengatasi konflik di dalam unitnya, kontribusi pemimpin terhadap peningkatan kemampuan keterampilan memecahkan masalah, kontribusi pemimpin terhadap kemampuan kelompok untuk menghadapi krisis, kontribusi pemimpin terhadap kemampuan kelompok untuk menyesuaikan dengan perubahan. Menurut Walumbwa et al. (2008) authentic leadership memiliki empat dimensi, seperti (1) Self-awareness. Kesadaran diri merupakan bagaimana cara seseorang untuk melihat diri sendiri, berusaha memahami diri mereka sendiri, dan mampu melihat dunia melalui proses. Mengetahui kekuatan dan kelemahan mereka, sehingga mereka sadar akan dampak apa yang akan diberikan kepada orang lain. (2) Relational transparency. Transparansi relasional merupakan sebuah perilaku untuk menampilkan diri mereka secara alami. Perilaku ini mengungkapkan berbagai informasi secara terbuka, dan pertunjukan ekspresi pikiran dan perasaan nyata, dengan demikian akan membangkitkan kepercayaan dari orang lain padanya melalui keterbukaan tersebut. (3) Balanced processing. Pemrosesan yang seimbang merupakan perilaku utama yang menunjukkan bahwa mereka menganalisis semua data secara relevan dan secara objektif sebelum mengambil sebuah keputusan. Pemimpin juga meminta pandangan orang lain, serta menerima masukan dan kritik dari orang lain yang menentang pendapatnya. (4) Internalized moral perspective. Internalisasi perspektif moral merupakan kemampuan untuk mengontrol dirinya sendiri. Pengaturan diri ini sesuai dengan nilai-nilai moral yang terinternalisasi dan tidak terintegrasi sesuai dengan moral suatu kelompok, masyarakat dan organisasi. 
Dari penelitian terdahulu dibuktikan bahwa terdapat hubungan positif antara authentic leadership dengan work engagement (Álvarez et al., 2019). Hal tersebut juga didukung oleh penelitian Oh et al. (2018) terdapat hubungan positif dari authentic leadership pada core values dan work engagement dan pada penelitian Miao et al (2018) mengatakan bahwa terdapat pengaruh antara emotional intelligence dan authentic leadership.

H2: Terdapat pengaruh yang signifikan authentic leadership (X2) terhadap work engagement ( $\mathrm{Y}$ ) saat pandemic COVID-19 pada tenaga kesehatan di kota Jakarta Barat.

H3: Terdapat pengaruh yang signifikan authentic leadership (X2) terhadap digital quotient (X1) saat pandemic COVID-19 pada tenaga kesehatan di kota Jakarta Barat.

\subsection{Perceived Organizational Support}

Perceived organizational support (POS) merupakan keyakinan karyawan mengenai bagaimana organisasi dapat menghargai kontribusi mereka dan peduli pada kesejahteraannya. Perceived organizational support mengarah pada pandangan karyawan tentang sejauh mana organisasi dapat memberi dukungan, menilai kontribusi dan peduli pada kesejahteraannya (Eisenberger, 2001). Menurut Rhoades dan Eisenberger (2001) mengatakan perceived organizational support adalah dukungan yang diberikan oleh organisasi yang dinilai melalui keyakinan tentang sejauh mana organisasi dapat memperhatikan kesejahteraannya, menilai kontribusi, memperhatikan kehidupan, mendengarkan keluhan, mempertimbangkan tujuan yang akan dicapai dan dapat dipercaya untuk memperlakukan karyawan dengan adil. Terdapat tiga dimensi perceived organizational support (POS) yang dapat meningkatkan dukungan organisasi yang dirasakan karyawan yaitu fairness, supervisor support, organization reward and job condition (Waileruny, 2014). Menurut Eisenberger et al. (2001) menyatakan bahwa variabel perceived organizational support dapat diukur melalui beberapa indikator, seperti (1). Perusahaan dapat menghargai kontribusi karyawan, (2) Organisasi cukup memberikan pengakuan kerja ekstra yang telah dilakukan oleh karyawannya, (3) Organisasi akan memberikan bantuan jika karyawan menghadapi kesulitan, (4) Organisasi akan menunjukkan prestasi karyawan terhadap karyawan yang lain, (5) Organisasi akan menanggapi jika karyawan memiliki keluhan, (6) Organisasi peduli dengan kesejahteraan karyawan, (7) Organisasi lebih memberikan perhatian kepada karyawan yang bekerja dengan baik.

Dari penelitian terdahulu telah membuktikan bahwa terdapat pengaruh yang signifikan antara perceived organizational support terhadap work engagement oleh Imran et al. (2020) dan didukung oleh penelitian lain yang juga memiliki pengaruh antara perceived organizational support terhadap work engagement (Stefanidis dan Strogilos, 2021). Hasil penelitian Bilgetürk dan Baykal (2021) juga menyatakan bahwa perceived organizational support berpengaruh signifikan terhadap authentic leadership dan penelitian Vermeulen dan Scheepers (2020) yang juga menunjukkan pengaruh yang kuat pada perceived organizational support dan authentic leadership.

H4: Terdapat pengaruh yang signifikan perceived organizational support (X3) terhadap work engagement (Y) saat pandemic COVID-19 pada tenaga kesehatan di kota Jakarta Barat.

H5: Terdapat pengaruh yang signifikan perceived organizational support (X3) terhadap digital quotient (X1) saat pandemic COVID-19 pada tenaga kesehatan di kota Jakarta Barat.

H6: Terdapat pengaruh yang signifikan perceived organizational support (X3) terhadap authentic leadership (X2) saat pandemic COVID-19 pada tenaga kesehatan di kota Jakarta Barat.

\section{Metode Penelitian}

Dalam penelitian ini metode yang digunakan yaitu kuantitatif. Pada penelitian kuantitatif arti dari kuantitatif ialah penelitian yang didasarkan oleh filsafat positivism, metode ini dipakai dalam melakukan riset sebuah populasi maupun sampel tersebut, untuk mengambil sampel umumnya dilakukan dengan cara acak, instrument pada penelitian dapat digunakan dalam mengumpulkan data, analisis data dengan sifat kuantitatif memiliki tujuan agar dapat mengui hipotesis yang telah ditetapkan (Sugiyono, 2017). Menurut Sugiyono (2017) data yang ditarik dari sebuah populasi merupakan metode penelitian survei yang dilakukan baik pada populasi yang besar ataupun kecil. 
Cross sectional merupakan time horizon yang dipakai pada penelitian ini, dimana pengumpulan data yang dilakukan hanya satu kali dalam periode, serta dapat menggunakan hasil untuk beberapa hari, minggu ataupun bulan untuk dapat menjawab pertanyaan di penelitian yang dilakukan (Sekaran \& Bougie, 2016). Pada penelitian ini terbagi menjadi dua (Sekaran dan Bougie, 2016) yaitu sumber data primer dimana data yang dikumpulkan dilakukan secara langsung yang memiliki tujuan untuk melihat spesifik penelitian dan sumber data sekunder berarti sebuah data yang sudah dikumpulkan dengan studi pustaka untuk mengetahui tujuan lain dari penelitian ini. Contoh sumber data sekunder seperti publikasi pemerintah, statistical bulletin, publish or unpublish information yang ada baik di dalam ataupun di luar organisasi, internet, dan situs web perusahaan.

\subsection{Teknik Pengambilan Sampel}

Besarnya sampel penelitian ini ditentukan dengan tabel krecjie yang didasarkan dengan kesalahan 0,05 atau 5\%. Sehingga jumlah sampel yang didaptkan memiliki tingkat kepercayaan 95\% dari populasi. Lihat pada tabel bahwa berapa banyak sampel yang harus dilihat dari populasi sudah cukup (Krecjie dan Morgan, 1970).

Tabel 1. Krecjie dan Morgan

\begin{tabular}{|c|c|c|c|c|c|}
\hline $\begin{array}{l}\text { Populasi } \\
\text { (N) }\end{array}$ & $\begin{array}{l}\text { Sampel } \\
\text { (S) }\end{array}$ & $\begin{array}{l}\text { Populasi } \\
\text { (N) }\end{array}$ & $\begin{array}{l}\text { Sampel } \\
\text { (S) }\end{array}$ & $\begin{array}{l}\text { Populasi } \\
\text { (N) }\end{array}$ & $\begin{array}{l}\text { Sampel } \\
\text { (S) }\end{array}$ \\
\hline 10 & 10 & 220 & 140 & 1200 & 291 \\
\hline 15 & 14 & 230 & 144 & 1300 & 297 \\
\hline 20 & 19 & 240 & 148 & 1400 & 302 \\
\hline 24 & 24 & 250 & 152 & 1500 & 306 \\
\hline 30 & 28 & 260 & 155 & 1600 & 310 \\
\hline 35 & 32 & 270 & 159 & 1700 & 313 \\
\hline 40 & 36 & 280 & 162 & 1800 & 317 \\
\hline 45 & 40 & 290 & 165 & 1900 & 320 \\
\hline 50 & 44 & 300 & 169 & 2000 & 322 \\
\hline 55 & 48 & 320 & 175 & 2200 & 327 \\
\hline 60 & 52 & 340 & 181 & 2400 & 331 \\
\hline 65 & 56 & 360 & 186 & 2600 & 335 \\
\hline 70 & 59 & 180 & 191 & 2800 & 338 \\
\hline 75 & 63 & 400 & 196 & 3000 & 341 \\
\hline 80 & 66 & 420 & 201 & 3500 & 346 \\
\hline 85 & 70 & 440 & 205 & 4000 & 351 \\
\hline 90 & 73 & 460 & 210 & 4500 & 354 \\
\hline 95 & 76 & 480 & 214 & 5000 & 357 \\
\hline 100 & 80 & 500 & 217 & 6000 & 361 \\
\hline 110 & 86 & 550 & 226 & 7000 & 364 \\
\hline 120 & 92 & 600 & 234 & 8000 & 367 \\
\hline 130 & 97 & 650 & 242 & 9000 & 368 \\
\hline 140 & 103 & 700 & 248 & 10000 & 370 \\
\hline 150 & 108 & 750 & 254 & 15000 & 375 \\
\hline 160 & 113 & 800 & 260 & 20000 & 377 \\
\hline 170 & 118 & 850 & 265 & 30000 & 379 \\
\hline
\end{tabular}




\begin{tabular}{|c|c|c|c|c|c|}
\hline 180 & 123 & 900 & 269 & 40000 & 380 \\
\hline 190 & 127 & 950 & 274 & 50000 & 381 \\
\hline 200 & 132 & 1000 & 278 & 75000 & 382 \\
\hline 210 & 136 & 1100 & 285 & 1000000 & 384 \\
\hline
\end{tabular}

Sumber: Krecjie dan Morgan (1970)

Pada table 1 dengan jumlah populasi 3337, maka jumlah populasi yang dilihat yang mendekati angka 3337 yaitu 3500 dengan jumlah sampel 346 responden. Setelah menyebar kuesioner, peneliti berhasil mendapatkan sebanyak 391 responden.

\subsection{Metode Pengumpulan Data}

Penelitian ini menggunakan Google Form untuk tempat menyebarkan kuesioner dan diukur menggunakan likert scale untuk mempermudah dalam pengolahan data. Penelitian ini memberikan nilai 1-5, dimana poin 1 (satu) "Tidak Pernah" adalah nilai terendah dan poin 5 (lima) "Selalu" adalah nilai tertinggi. Peneliti mendapatkan sebanyak 391 responden setelah menyebar kuesioner.

\subsection{Metode Analisis Data}

Software SPSS 25 merupakan aplikasi yang digunakan dalam metode penelitian ini, tujuannya agar mempermudah. Metode yang dipakai sebagai berikut:

- Statistik Deskriptif

Menurut Sugiyono (2017) statistik deskriptif merupakan cara menganalisis data dengan mendeskripsikan maupun menggambarkan data yang terkumpul denga napa adanya tanpa memiliki maksud membuat kesimpulan yang berlaku untuk generalisasi atau umum.

- Uji Validitas

Ghozali (2018) mengatakan hasil penelitian dinyatakan valid ketika pernyataan kuesioner dapat menerangkan sesuatu dimana hasil dari penelitian bisa mengukur yang diukur oleh penliti. Penulis memakai Pearson Correlation dengan total skor variabel dengan signigikasi 5\%.

Dasar Pengambilan Keputusan:

* Jika nilai Rhitung $\geq$ Rtabel, maka hipotesis diterima. Jadi dapat disimpulkan bahwa butir pertanyaan valid.

* Jika nilai Rhitung < Rtabel, maka hipotesis ditolak. Jadi dapat disimpulkan bahwa butir pertanyaan tidak valid

- Uji Reliabilitas

Reliabilitas merupakan alat untuk menghitung indikator dari variabel pada kuesioner (Ghozali, 2018). Dasar Pengambilan Keputusan:

* Jika nilai Roc $\geq 0,6$, maka hipotesis diterima. Jadi dapat disimpulkan bahwa butir pertanyaan reliabel.

* Jika nilai Roc < 0,6, maka hipotesis ditolak. Jadi dapat disimpulkan bahwa butir pertanyaan tidak reliabel.

- Uji Korelasi

Analisis korelasi merupakan kumpulan dari berbagai teknik dalam menghitung hubungan antara dua variabel (Lind et al., 2012). Besar nilai koefisien korelasi memiliki nilai antara +1 sampai -1 . ada di interpretasi 0 , maka masuk kategori tidak ada korelasi antara dua variabel. Jika ada di interpretasi $>0$ - 0,25, maka masuk kategori korelasi sangat lemah; >0,25 - 0,5, maka masuk kategori korelasi cukup. Jika ada di interpretasi $>0,5-0,75$, maka masuk kategori korelasi kuat. Jika ada di interpretasi $>0,75$ - 0,99, maka masuk kategori korelasi sangat kuat. Jika ada di interpretasi 1, maka masuk kategori korelasi sempurna. 
- Uji Tabulasi Silang (Uji Z)

Uji ini dilakukan untuk mengetahui apakah hasil pembelajaran dalam penelitian ini terdapat perbedaan atau tidak antara variabel dengan profil responden. Dengan keputusan apabila $Z$ hitung < $\mathrm{Z}$ tabel, maka hipotesis diterima. Sehingga mendapatkan kesimpulan tidak ada perbedaan antara variabel dengan profil responden dan begitu pula sebaliknya.

- Uji Hipotesis (Regresi Berganda)

Analisis regresi berganda ialah regresi yang diginakan untuk memperkirakan nilai variabel dependen yang didasarkan nilai dari dua variabel independent ataupun lebih.

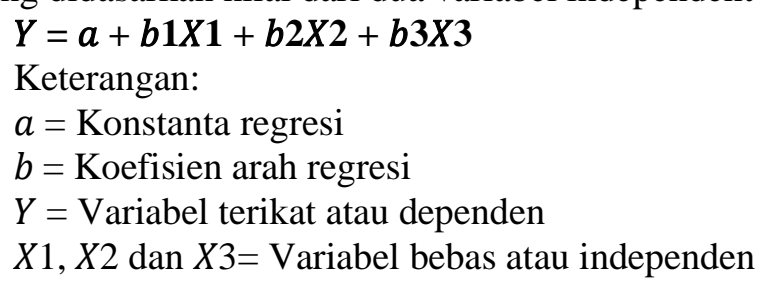

Dengan pengambilan keputusan $X 1, X 2$, dan $X 3$ berpengaruh terhadap $Y$ jika $b 1, b 2$, dan $b 3 \neq 0$

- Uji Hipotesis (Regresi Sederhana)

Analisis regresi sederhana adalah analisis regresi yang memiliki tujuan untuk mengetahui hubungan antara satu variabel dependen dengan satu variabel independen. Persamaan regresi sederhana:

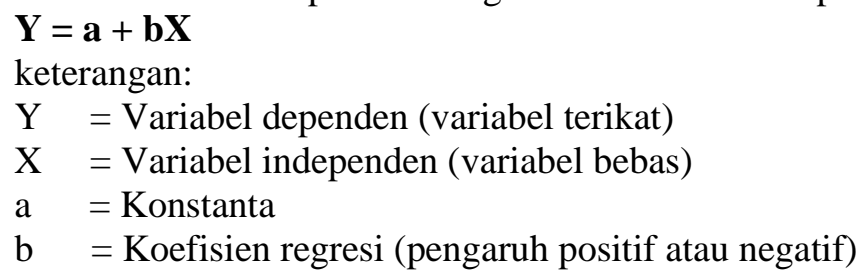

Dasar Pengambilan Keputusan:

* Diterima jika nilai sig $\geq \alpha$ dan Thitung $\leq$ Ttabel, maka hipotesis diterima. Jadi dapat disimpulkan bahwa tidak terdapat pengaruh yang signifikan antara satu variabel independen terhadap variabel dependen.

* Ditolak jika nilai nilai sig $<\alpha$ dan Thitung $>$ Ttabel, maka hipotesis diterima. Jadi dapat disimpulkan bahwa tidak terdapat pengaruh yang signifikan antara satu variabel independen terhadap variabel dependen.

- Uji Koefisien Determinasi Koefisien determinasi merupakan nilai yang memperlihatkan seberapa besar variabel independen yang dapat menjelaskan variabel dependen. Menurut Ghozali (2011) nilai yang mendekati 1 berarti variabel independen memberikan hampir semua informasi yang dibutuhkan untuk memprediksi variabel dependen, sedangkan nilai yang kecil memiliki arti kemampuan variabel independen dalam menjelaskan variabel dependennya terbatas.

- Uji T

Uji t memiliki tujuan untuk mengetahui sebesar apa pengaruh dari variabel bebas dalam menerangkan variabel terikat (Kuncoro, 2013). Hasil uji t dengan t tabel akan dilakukan perbandingan yang menggunakan tingkat kesalahan 5\% atau 0,05 . Keputusan akan diterima jika nilai sig $<\alpha$ begitu juga sebaliknya. Jadi apabila Ho diterima maka tidak terdapat pengaruh signifikan, begitu pula sebaliknya. 


\section{Hasil dan Pembahasan}

\subsection{Profil Responden Penelitian}

Tabel 2. Profil Responden Penelitian

\begin{tabular}{|c|c|c|c|}
\hline Kategori & $\begin{array}{c}\text { Jumlah } \\
\text { Responden }\end{array}$ & Persentase & Kumulatif \\
\hline \multicolumn{4}{|c|}{ Tahun Kelahiran } \\
\hline 1960-1969 & 4 & $1 \%$ & $1 \%$ \\
\hline $1970-1979$ & 10 & $3 \%$ & $4 \%$ \\
\hline 1980-1989 & 20 & $5 \%$ & $9 \%$ \\
\hline 1990-1999 & 294 & $75 \%$ & $84 \%$ \\
\hline$>2000$ & 63 & $16 \%$ & $100 \%$ \\
\hline \multicolumn{4}{|c|}{ Jenis Kelamin } \\
\hline Wanita & 262 & $67 \%$ & $67 \%$ \\
\hline Pria & 129 & $33 \%$ & $100 \%$ \\
\hline \multicolumn{4}{|c|}{ Status Pernikahan } \\
\hline Menikah & 79 & $20 \%$ & $20 \%$ \\
\hline Belum Menikah & 312 & $80 \%$ & $100 \%$ \\
\hline \multicolumn{4}{|c|}{ Golongan Darah } \\
\hline A & 73 & $19 \%$ & $19 \%$ \\
\hline $\mathrm{B}$ & 87 & $22 \%$ & $41 \%$ \\
\hline $\mathrm{AB}$ & 48 & $12 \%$ & $53 \%$ \\
\hline $\mathrm{O}$ & 183 & $47 \%$ & $100 \%$ \\
\hline \multicolumn{4}{|c|}{ Tahun Mulai Kerja } \\
\hline 1 tahun -3 tahun & 260 & $66,50 \%$ & $66,50 \%$ \\
\hline 3 tahun -6 tahun & 87 & $22,25 \%$ & $88,75 \%$ \\
\hline 6 tahun -10 tahun & 27 & $6,91 \%$ & $95,65 \%$ \\
\hline$>10$ tahun & 17 & $4,35 \%$ & $100 \%$ \\
\hline \multicolumn{4}{|c|}{ Kepribadian } \\
\hline Introvert & 200 & $51 \%$ & $51 \%$ \\
\hline Ekstrovert & 191 & $49 \%$ & $100 \%$ \\
\hline \multicolumn{4}{|c|}{ Kebiasaan } \\
\hline Tim bubur diaduk & 189 & $48 \%$ & $48 \%$ \\
\hline $\begin{array}{c}\text { Tim bubur tidak } \\
\text { diaduk }\end{array}$ & 145 & $37 \%$ & $85 \%$ \\
\hline $\begin{array}{l}\text { Tim tidak suka } \\
\text { makan bubur }\end{array}$ & 57 & $15 \%$ & $100 \%$ \\
\hline
\end{tabular}

Sumber: Analisis Peneliti (2021)

Untuk melakukan penelitian, mengumpulkan profil responden merupakan hal yang penting karena didalamnya terdapat indikator untuk mengukur digital quotient, authentic leadership dan perceived organizational support terhadap work engagement. Dari tabel 2 diperoleh sebanyak $75 \%$ didominasi oleh responden yang lahir tahun 1990-1999 atau pada usia 22-31 tahun dengan wanita mendominasi sebanyak $67 \%$. Status pernikahan didominasi dengan $80 \%$ belum menikah dengan golongan darah $\mathrm{O}$ mendominasi $47 \%$. Tenaga kesehatan dengan lama bekerja kurang dari 3 tahun mendominasi dengan $66,5 \%$, dilanjutkan dengan kepribadian introvert yang mendominasi $51 \%$ dan sisanya ekstrovert serta kebiasaan tim bubur diaduk mendominasi $48 \%$. Hal ini untuk mengetahui tahun kelahiran, jenis kelamin, status pernikahan, golongan darah, lama bekerja, kepribadian dan kebiasaan makan bubur 
karena penelitian terdahulu menyatakan perbedaan demografi tersebut berpengaruh dalam tingkat work engagement, digital quotient, authentic leadership, dan perceived organizational support.

\subsection{Analisis Deskriptif Variabel}

Tabel 3. Analisis Deskriptif Variabel

\begin{tabular}{|c|c|c|c|c|c|}
\hline $\begin{array}{c}\text { Variabel / Dimensi / } \\
\text { Item }\end{array}$ & Indikator & $\mathbf{N}$ & Validitas & Reliabilitas & $\begin{array}{l}\text { Rata- } \\
\text { Rata }\end{array}$ \\
\hline Work Engagement & & & & $\mathbf{0 , 8 4 2}$ & 3,68 \\
\hline Physically Engaged & & & & & 3,89 \\
\hline PE01 & $\begin{array}{l}\text { Selalu bersemangat di tempat } \\
\text { kerja }\end{array}$ & 391 & 0,795 & & 3,97 \\
\hline PE02 & $\begin{array}{l}\text { Sanggup bekerja dalam waktu } \\
\text { yang lama }\end{array}$ & 391 & 0,582 & & 3,72 \\
\hline PE03 & $\begin{array}{l}\text { Bekerja menjadikan tubuh } \\
\text { semakin sehat }\end{array}$ & 391 & 0,741 & & 3,98 \\
\hline $\begin{array}{l}\text { Intellectually } \\
\text { Engaged }\end{array}$ & & & & & 3,95 \\
\hline IE01 & Kemampuan berpikir maju & 391 & 0,761 & & 3,94 \\
\hline IE02 & $\begin{array}{l}\text { Mendapatkan banyak ide } \\
\text { kreatif }\end{array}$ & 391 & 0,72 & & 3,85 \\
\hline IE03 & Fokus dan konsentrasi penuh & 391 & 0,66 & & 4,05 \\
\hline $\begin{array}{l}\text { Emotionally } \\
\text { Engaged }\end{array}$ & & & & & 2,98 \\
\hline EE01 & Bangga dengan pekerjaan & 391 & 0,559 & & 4,18 \\
\hline EE02 & Berat untuk berganti pekerjaan & 391 & 0,376 & & 2,50 \\
\hline EE03 & $\begin{array}{l}\text { Tidak mengeluh ketika } \\
\text { diberikan banyak kerjaan }\end{array}$ & 391 & 0,105 & & 2,26 \\
\hline Spiritually Engaged & & & & & 3,89 \\
\hline SE01 & $\begin{array}{l}\begin{array}{l}\text { Menemukan makna dalam } \\
\text { kehidupan }\end{array} \\
\end{array}$ & 391 & 0,503 & & 3,91 \\
\hline SE02 & $\begin{array}{l}\text { Pekerjaan sebagai panggilan } \\
\text { hidup }\end{array}$ & 391 & 0,619 & & 3,65 \\
\hline SE03 & $\begin{array}{l}\begin{array}{l}\text { Kesempatan untuk dapat } \\
\text { bermanfaat }\end{array} \\
\end{array}$ & 391 & 0,668 & & 4,06 \\
\hline SE04 & $\begin{array}{l}\text { Merasakan akan kehadiran } \\
\text { Tuhan }\end{array}$ & 391 & 0,666 & & 3,93 \\
\hline Digital Quotient & & & & 0,754 & 3.77 \\
\hline Digital Identity & & & & & 4.10 \\
\hline DI01 & $\begin{array}{l}\text { Menggunakan nama asli dalam } \\
\text { profil media digital }\end{array}$ & 391 & 0,534 & & 4.15 \\
\hline DI02 & $\begin{array}{l}\text { Menggunakan foto asli dalam } \\
\text { profil media digital }\end{array}$ & 391 & 0,373 & & 4.18 \\
\hline DI03 & $\begin{array}{l}\text { Berhenti berkomunikasi } \\
\text { dengan orang yang berperilaku } \\
\text { buruk di media digital }\end{array}$ & 391 & 0,454 & & 3.96 \\
\hline Digital Use & & & & & 3.31 \\
\hline DU01 & $\begin{array}{l}\text { Tidak mengakses media digital } \\
\text { saat jam kerja }\end{array}$ & 391 & 0,21 & & 3.16 \\
\hline DU03 & $\begin{array}{ll}\text { Menggunakan media digital } \\
\text { untuk bekerja } \\
\text { mengembangkan diri }\end{array}$ & 391 & 0,352 & & 3.46 \\
\hline
\end{tabular}




\begin{tabular}{|c|c|c|c|c|}
\hline Digital Safety & & & & 3.56 \\
\hline DF01 & $\begin{array}{l}\text { Menghindari dan } \\
\text { menghentikan komunikasi saat } \\
\text { merasa terancam oleh } \\
\text { pengguna media digital lainnya }\end{array}$ & 391 & 0,53 & 3.58 \\
\hline DF02 & $\begin{array}{l}\text { Menghindari dan } \\
\text { menghentikan komunikasi saat } \\
\text { diintimidasi dengan kalimat } \\
\text { atau gambar }\end{array}$ & 391 & 0,544 & 3.43 \\
\hline DF03 & $\begin{array}{l}\text { Menghindari dan } \\
\text { menghentikan komunikasi saat } \\
\text { ada yang meminta informasi } \\
\text { pribadi di media digital }\end{array}$ & 391 & 0,684 & 3.67 \\
\hline Digital Security & & & & 3.96 \\
\hline DS01 & $\begin{array}{l}\text { Tidak mengakses konten } \\
\text { memalukan dan situs porno }\end{array}$ & 391 & 0,162 & 3.73 \\
\hline DS02 & $\begin{array}{lr}\text { Mengabaikan } & \text { orang } \\
\text { mencurigakan yang terlihat } \\
\text { mengancam keamanan media } \\
\text { digital }\end{array}$ & 391 & 0,621 & 3.82 \\
\hline DS03 & $\begin{array}{l}\text { Menggunakan kata sandi yang } \\
\text { tidak diketahui oleh siapapun } \\
\text { untuk melindungi keamanan } \\
\text { media digital }\end{array}$ & 391 & 0,503 & 4.34 \\
\hline $\begin{array}{l}\text { Digital Emotional } \\
\text { Intelligence }\end{array}$ & & & & 3.80 \\
\hline DE01 & $\begin{array}{l}\text { Menaruh simpati kepada orang } \\
\text { lain saat mereka membagikan } \\
\text { pesan sedih dengan membalas } \\
\text { pesan untuk menghibur }\end{array}$ & 391 & 0,619 & 3.83 \\
\hline DE02 & $\begin{array}{l}\text { Memberikan saran saat } \\
\text { seseorang membagikan pesan } \\
\text { meminta bantuan }\end{array}$ & 391 & 0,481 & 3.75 \\
\hline DE03 & $\begin{array}{l}\text { Menggunakan media digital } \\
\text { sebagai media mengungkapkan } \\
\text { perasaan khawatir terhadap } \\
\text { teman dan kolega }\end{array}$ & 391 & 0,393 & 3.81 \\
\hline $\begin{array}{l}\text { Digital } \\
\text { Communication }\end{array}$ & & & & 3.77 \\
\hline DC01 & $\begin{array}{l}\text { Menyapa dan bertanya dengan } \\
\text { bahasa yang sopan }\end{array}$ & 391 & 0,202 & 3.82 \\
\hline $\mathrm{DC} 02$ & $\begin{array}{l}\text { Menggunakan media digital } \\
\text { sebagai sarana untuk dapat } \\
\text { bekerja dengan orang lain }\end{array}$ & 391 & 0,516 & 3.96 \\
\hline DC03 & $\begin{array}{l}\text { Media digital menjadikan } \\
\text { bekerja lebih efisien }\end{array}$ & 391 & 0,459 & 3.53 \\
\hline Digital Literacy & & & & 3.71 \\
\hline DL01 & $\begin{array}{l}\text { Menggunakan media digital } \\
\text { untuk mencari informasi di } \\
\text { tempat kerja }\end{array}$ & 391 & 0,562 & 3.98 \\
\hline
\end{tabular}




\begin{tabular}{|c|c|c|c|c|c|}
\hline DL02 & $\begin{array}{l}\text { Memilih sumber informasi } \\
\text { yang dapat dipercaya dalam } \\
\text { media digital }\end{array}$ & 391 & 0,223 & & 3.71 \\
\hline DL03 & $\begin{array}{l}\text { Informasi dari media digital } \\
\text { meningkatkan efisiensi dalam } \\
\text { bekerja }\end{array}$ & 391 & 0,492 & & 3.45 \\
\hline Digital Rights & & & & & 3.92 \\
\hline DR01 & $\begin{array}{l}\text { Selalu merujuk pada pemilik } \\
\text { atau sumber saat menggunakan } \\
\text { karya orang lain }\end{array}$ & 391 & 0,483 & & 3.78 \\
\hline DR02 & $\begin{array}{lrr}\text { Tidak melanggar hak privasi } \\
\text { dan undang-undang } \\
\text { berbagi informasi di media } \\
\text { digital }\end{array}$ & 391 & 0,517 & & 3.99 \\
\hline DR03 & $\begin{array}{l}\text { Memahami bahwa hal yang } \\
\text { dikomunikasikan dalam media } \\
\text { digital adalah tanggung jawab } \\
\text { dalam bermasyarakat }\end{array}$ & 391 & 0,594 & & 4.00 \\
\hline $\begin{array}{l}\text { Authentic } \\
\text { Leadership }\end{array}$ & & & & $\mathbf{0 , 8 8 9}$ & 3.71 \\
\hline Self-awareness & & & & & 3.63 \\
\hline SA01 & $\begin{array}{l}\text { Pemimpin dapat membuat } \\
\text { daftar kelemahannya }\end{array}$ & 391 & 0,485 & & 3.48 \\
\hline SA02 & $\begin{array}{l}\text { Pemimpin dapat membuat } \\
\text { daftar kekuatannya }\end{array}$ & 391 & 0,588 & & 3.76 \\
\hline SA03 & $\begin{array}{lrr}\begin{array}{l}\text { Pemimpin mencari } \\
\text { untuk meedback } \\
\text { dirinya }\end{array} & & \\
\end{array}$ & 391 & 0,661 & & 3.65 \\
\hline $\begin{array}{l}\text { Relational } \\
\text { Transparency }\end{array}$ & & & & & 3.74 \\
\hline RT02 & $\begin{array}{l}\text { Orang lain mengetahui dimana } \\
\text { pemimpin akan berpihak saat } \\
\text { terjadi masalah tertentu }\end{array}$ & 391 & 0,662 & & 3.73 \\
\hline RT03 & $\begin{array}{llr}\text { Pemimpin } & & \text { dapat } \\
\text { mencerminkan } & \text { nilai } & \text { dalam } \\
\text { tindakannya } & & \\
\end{array}$ & 391 & 0,747 & & 3.75 \\
\hline Balanced Processing & & & & & 3.77 \\
\hline BR01 & $\begin{array}{l}\text { Pemimpin mencari pendapat } \\
\text { lain sebelum mengambil } \\
\text { keputusan }\end{array}$ & 391 & 0,788 & & 3.77 \\
\hline BR02 & $\begin{array}{l}\text { Pemimpin tidak memaksakan } \\
\text { sudut pandangnya dengan } \\
\text { mengorbankan orang lain }\end{array}$ & 391 & 0,765 & & 3.67 \\
\hline BR03 & $\begin{array}{l}\text { Pemimpin mendengarkan } \\
\text { pendapat dari orang yang tidak } \\
\text { setuju dengannya }\end{array}$ & 391 & 0,771 & & 3.88 \\
\hline $\begin{array}{l}\text { Internalized Moral } \\
\text { Perspective }\end{array}$ & & & & & 3.69 \\
\hline IM01 & $\begin{array}{l}\text { Pemimpin dapat berbagi } \\
\text { perasaannya dengan lainnya }\end{array}$ & 391 & 0,612 & & 3.67 \\
\hline IM02 & $\begin{array}{l}\text { Pemimpin jarang menyalahkan } \\
\text { di depan orang lain }\end{array}$ & 391 & 0,666 & & 3.51 \\
\hline
\end{tabular}




\begin{tabular}{|c|c|c|c|c|c|}
\hline IM03 & $\begin{array}{l}\text { Pemimpin menunjukkan } \\
\text { kepribadian yang sebenarnya } \\
\text { kepada lainnya }\end{array}$ & 391 & 0,609 & & 3.88 \\
\hline $\begin{array}{l}\text { Perceived } \\
\text { Organizational } \\
\text { Support }\end{array}$ & & & & 0,917 & 3.86 \\
\hline Fairness & & & & & 3.79 \\
\hline FD01 & $\begin{array}{l}\text { Memiliki prosedur yang adil } \\
\text { bagi setiap karyawan }\end{array}$ & 391 & 0,728 & & 3.86 \\
\hline FD02 & $\begin{array}{l}\text { Memiliki komunikasi yang } \\
\text { terbuka bagi penempatan } \\
\text { karyawan }\end{array}$ & 391 & 0,673 & & 3.64 \\
\hline FD03 & $\begin{array}{l}\text { Memberikan kesempatan untuk } \\
\text { berkembang bagi setiap } \\
\text { karyawan }\end{array}$ & 391 & 0,76 & & 3.86 \\
\hline Supervisor Support & & & & & 3.92 \\
\hline SS01 & $\begin{array}{l}\text { Tidak mengabaikan keluhan } \\
\text { karyawan }\end{array}$ & 391 & 0,654 & & 3.86 \\
\hline SS02 & $\begin{array}{lr}\begin{array}{l}\text { Menunjukan } \\
\text { terhadap } \\
\text { karyawan }\end{array} & \text { kepedulian } \\
\text { kesejahteraan }\end{array}$ & 391 & 0,753 & & 3.91 \\
\hline SS03 & $\begin{array}{l}\text { Menghargai upaya ekstra dari } \\
\text { karyawan }\end{array}$ & 391 & 0,731 & & 3.94 \\
\hline SS04 & $\begin{array}{l}\text { Bangga terhadap keberhasilan } \\
\text { karyawan }\end{array}$ & 391 & 0,691 & & 3.98 \\
\hline $\begin{array}{l}\text { Organization } \\
\text { Reward dan Job } \\
\text { Condition } \\
\end{array}$ & & & & & 3.88 \\
\hline OJ01 & $\begin{array}{l}\text { Menghargai kontribusi } \\
\text { karyawan bagi organisasi }\end{array}$ & 391 & 0,779 & & 3.92 \\
\hline OJ02 & $\begin{array}{l}\text { Peduli tentang pembayaran } \\
\text { yang diterima setiap karyawan }\end{array}$ & 391 & 0,73 & & 3.83 \\
\hline OJ03 & $\begin{array}{l}\text { Memberikan kesempatan untuk } \\
\text { setiap jenjang karir. }\end{array}$ & 391 & 0,749 & & 3.81 \\
\hline OJ04 & $\begin{array}{l}\text { Menyediakan keamanan bagi } \\
\text { karyawan dalam bekerja }\end{array}$ & 391 & 0,752 & & 3.94 \\
\hline OJ05 & $\begin{array}{l}\text { Menyediakan pelatihan yang } \\
\text { sesuai dengan pekerjaan } \\
\text { karyawan }\end{array}$ & 391 & 0,669 & & 3.90 \\
\hline
\end{tabular}

Sumber: Analisis Peneliti (2021)

- Validitas dan Reliabilitas

Dapat dilihat pada tabel 3 hasil validitas pada butir pertanyaan variabel work engagement, digital quotient, authentic leadership dan perceived organizational support memiliki nilai $\mathrm{R}$ hitung $>\mathrm{R}$ tabel $(0,1)$, sehingga bisa ditarik kesimpulan bahwa semua butir pertanyaan pada work engagement, digital quotient, authentic leadership dan perceived organizational support merupakan valid. Dari hasil reliabilitas didapatkan hasil bahwa semua variabel work engagement, digital quotient, authentic leadership dan perceived organizational support memiliki nilai Cronbach's Alpha > 0,6, yang bisa disimpulkan bahwa variabel work engagement, digital quotient, authentic leadership dan perceived organizational support reliabel. 


\section{- Variabel Work Engagement}

Ketika mengetahui tingkat work engagement tenaga kesehatan, ketertarikan kerja pada tenaga kesehatan harus bisa ditingkatkan oleh perusahaan. Hal ini dapat diketahui dengan melihat kurangnya rasa terikat secara emosional saat menjalankan pekerjaannya merasa ingin pindah pekerjaan dan merasa lelah dengan banyaknya pekerjaan yang diberikan.

Berdasarkan tabel 3 diketahui hasil bahwa tenaga kesehatan memiliki tingkat work engagement yang masuk kategori tinggi dengan nilai 3,68. Seluruh dimensi variabel work engagement termasuk kedalam kategori tinggi dengan nilai physical engaged $(3,89)$, intellectually engaged $(3,95)$, emotionally engaged $(2,98)$ dan spiritually engaged $(3,89)$. EE01 (bangga dengan pekerjaan) dengan rata rata $(4,18)$ dan masuk kategori tinggi merupakan indikator dengan jawaban yang paling tinggi. Hal ini membuktikan bahwa tenaga kesehatan yang bekerja di Jakarta Barat menganggap pekerjaan mereka telah menjadi kebanggaan dan kepentingan untuk bekerja dengan maksimal. EE03 (tidak mengeluh saat diberikan banyak pekerjaan) merupakan indikator dengan rata-rata respon yang paling rendah $(2,26)$ serta masuk ke kategori rendah.

\section{- Variabel Digital Quotient}

Diketahuinya tingkat digital quotient tenaga kesehatan, perusahaan diharapkan dapat mengarahkan penguasaan serta penggunakan kecerdasan digital. Hal tersebut dilakukan agar tenaga kesehatan dapat memanfaatkannya dengan baik dan agar dapat menghindari kejahatan digital seperti peretasan, hingga tersebarnya informasi pribadi.

Berdasarkan tabel 3 didapatkan hasil tingkat nilai digital quotient tenaga kesehatan $(3,77)$ dan masuk kategori tinggi. Nilai untuk setiap dimensi digital quotient termasuk dalam kategori tinggi dengan tingkat nilai digital identity $(4,10)$, digital use $(3,31)$, digital safety $(3,56)$, digital security $(3,96)$, digital emotional intelligence $(3,80)$, digital communication $(3,77)$, digital literacy $(3,71)$ dan digital rights $(3,92)$. DS03 (menggunakan kata sandi) memiliki nilai $(4,34)$ yang menjadikannya indikator dengan rata-rata respon jawaban yang paling tinggi juga masuk kategori sangat tinggi. Sehingga ini menunjukkan bahwa tenaga kesehatan yang bekerja di Jakarta Barat menganggap bahwa menggunakan kata sandi di social media sangatlah penting untuk menjaga keamanan informasi. Indikator DU01 (tidak mengakses media digital saat jam kerja) masuk dalam kategori sedang dengan menjadi nilai rata-rata $(3,16)$.

\section{- Variabel Authentic Leadership}

Ketika mendapatkan tingkat authentic leadership tenaga kesehatan, perusahaan diharapkan dapat mempertahankan kualitas pemimpin yang dapat mendengarkan pendapat orang lain. Hal tersebut dilakukan agar tenaga kesehatan dapat bekerja dengan performa kinerja yang optimal. Berdasarkan tabel 3 menunjukkan hasil tenaga kesehatan memiliki tingkat authentic leadership senilai $(3,71)$ yang termasuk dalam kategori tinggi. Jika melihat dimensi authentic leadership memiliki tingkat selfawareness $(3,63)$, relational transparency $(3,74)$, balance processing $(3,77)$ dan internalized moral perspective $(3,69)$ yang masuk dalam kategori tinggi. Indikator dengan rata-rata respon jawaban paling tinggi yaitu BR03 (pemimpin mendengarkan pendapat dari orang yang tidak setuju dengannya) dan IM03 (Pemimpin menunjukkan kepribadian yang sebenarnya kepada lainnya) dengan skor yang sama sebesar $(3,88)$ masuk kategori tinggi. Hal ini memperlihatkan bahwa tenaga kesehatan yang bekerja di Jakarta Barat menganggap bahwa pemimpin yang mendengarkan pendapat orang lain dan menjadi dirinya sendiri merupakan pemimpin yang dibutuhkan dalam bekerja. SA01 (Pemimpin dapat membuat daftar kelemahannya) merupakan indikator dengan rata-rata yang rendah diantara yang lainnya $(3,48)$ namun tetap masuk dalam kategori tinggi.

\section{- Variabel Perceived Organizational Support}

Dengan melihat tingkat perceived organizational support tenaga kesehatan, perusahaan diharapkan dapat menghargai dan merasa bangga atas kerja keras serta keberhasilan tenaga kesehatan. Hal tersebut dilakukan agar tenaga kesehatan dapat meningkatkan performa kinerja demi kesuksesan bersama.

Berdasarkan tabel 3 hasil bahwa tenaga kesehatan yang bekerja di Jakarta Barat memiliki nilai tingkat perceived organizational support $(3,86)$ masuk ke kategori tinggi dan apabila melihat per dimensi 
variabel perceived organizational support mempunyai tingkat fairness $(3,79)$, supervisor support $(3,92)$ dan organization reward and job condition $(3,88)$ yang masuk dalam kategori tinggi. SS04 (bangga terhadap keberhasilan karyawan) menjadi indikator dengan rata-rata yang paling tinggi $(3,98)$ sehingga termasuk kategori tinggi. Dalam hal ini mengungkapkan bahwa tenaga kesehatan yang bekerja di Jakarta Barat memiliki pandangan bahwa keberhasilan karyawan dipengaruhi oleh dukungan perusahaan. FD02 (memiliki komunikasi yang terbuka bagi penempatan karyawan) menjadi indikator dengan rata-rata respon jawaban yang paling rendah diantara lainnya $(3,64)$ namun masuk dalam kategori tinggi.

\subsection{Uji Tabulasi Silang}

- Berdasarkan Tahun Lahir

Tabel 4. Hasil Tabulasi Silang Berdasarkan Jenis Kelamin

\begin{tabular}{|c|c|c|c|c|c|c|}
\hline Tahun Lahir & Jumlah & Mean & Std.Deviation & Zhitung & Ztabel & Kesimpulan \\
\hline$<1890$ & 34 & 4.07 & 0.45 & \multirow{2}{*}{4.94} & \multirow{2}{*}{1.96} & \multirow{2}{*}{ Signifikan } \\
\hline $1890-2002$ & 357 & 3.66 & 0.58 & & & \\
\hline
\end{tabular}

Sumber: Analisis Peneliti (2021)

Berdasarkan table 4 hasil tabulasi silang pada variabel work engagement untuk tahun lahir didapatkan $\mathrm{Z}$ hitung $(4,94)>\mathrm{Z}$ tabel $(1,96)$ dan mendapatkan kesimpulan bahwa Ho ditolak, maka work engagement tenaga kesehatan berdasarkan tahun lahir ada perbedaan.

- Berdasarkan Jenis Kelamin

Tabel 5. Tabulasi Silang Berdasarkan Jenis Kelamin

\begin{tabular}{|c|c|c|c|c|c|c|}
\hline Jenis Kelamin & Jumlah & Mean & Std.Deviation & Zhitung & Ztabel & Kesimpulan \\
\hline Wanita & 262 & 3,69 & 0,57 & \multirow{2}{*}{$-0,16$} & \multirow{2}{*}{1,96} & $\begin{array}{c}\text { Tidak } \\
\text { Signifikan }\end{array}$ \\
\hline Pria & 129 & 3,70 & 0,60 & & & \\
\hline
\end{tabular}

Sumber: Analisis Peneliti (2021)

Berdasarkan table 5 hasil tabulasi silang pada variabel work engagement untuk jenis kelamin $\mathrm{Z}$ hitung mendapatkan nilai $-0,16<Z$ tabel dengan nilai 1,96 . Sehingga Ho diterima, maka work engagement tenaga kesehatan berdasarkan jenis kelamin tidak ada perbedaan.

- Berdasarkan Status Pernikahan

Tabel 6. Tabulasi Silang Berdasarkan Status Pernikahan

\begin{tabular}{|c|c|c|c|c|c|c|}
\hline Status Pernikahan & Jumlah & Mean & Std.Deviation & Zhitung & Ztabel & Kesimpulan \\
\hline Menikah & 79 & 3.84 & 0.66 & \multirow{2}{*}{2.22} & \multirow{2}{*}{1.96} & \multirow{2}{*}{ Signifikan } \\
\hline Belum Menikah & 312 & 3.66 & 0.56 & & & \\
\hline \multicolumn{7}{|c|}{ Sumber: Analisis Peneliti (2021) }
\end{tabular}

Berdasarkan table 6 hasil tabulasi silang pada variabel work engagement untuk status pernikahan didapatkan $\mathrm{Z}$ hitung sebanyak 2,22 > Z tabel sebesar 1,96. Sehingga bisa mendapatkan kesimpulan Ho ditolak, maka work engagement tenaga kesehatan berdasarkan status pernikahan ada perbedaan.

- Berdasarkan Golongan Darah

Tabel 7. Tabulasi Silang Berdasarkan Golongan Darah

\begin{tabular}{|c|c|c|c|c|c|c|}
\hline Golongan Darah & Jumlah & Mean & Std.Deviation & Zhitung & Ztabel & Kesimpulan \\
\hline Golongan Darah O & 183 & 3.79 & 0.56 & \multirow{2}{*}{3.28} & \multirow{2}{*}{1.96} & \multirow{2}{*}{ Signifikan } \\
\cline { 1 - 4 } Non Golongan Darah O & 208 & 3.6 & 0.59 & & & \\
\hline
\end{tabular}

Sumber: Analisis Peneliti (2021) 
Berdasarkan tabel 7 hasil tabulasi silang pada variabel work engagement untuk golongan darah nilai $\mathrm{Z}$ hitung $(3,28)>$ nilai $\mathrm{Z}$ tabel $(1,96)$. Maka Ho ditolak, sehingga work engagement tenaga kesehatan berdasarkan golongan darah ada perbedaan.

- Berdasarkan Lama Bekerja

Tabel 8 Tabulasi Silang Berdasarkan Lama Bekerja

\begin{tabular}{|c|c|c|c|c|c|c|}
\hline Lama Bekerja & Jumlah & Mean & Std.Deviation & Zhitung & Ztabel & Kesimpulan \\
\hline 1 Tahun - 10 Tahun & 368 & 3.69 & 0.58 & \multirow{2}{*}{-0.44} & \multirow{2}{*}{1.96} & $\begin{array}{c}\text { Tidak } \\
\text { Signifikan }\end{array}$ \\
\hline > 10 Tahun & 23 & 3.75 & 0.64 & & & . \\
\hline
\end{tabular}

Sumber: Analisis Peneliti (2021)

Berdasarkan tabel 8 hasil tabulasi silang pada variabel work engagement untuk lama bekerja memiliki $\mathrm{Z}$ hitung sebesar $-0,44<\mathrm{Z}$ tabel sebesar 1,96. Sehingga Ho diterima, maka work engagement tenaga kesehatan berdasarkan lama bekerja tidak ada perbedaan.

- Berdasarkan Beda Kepribadian

Tabel 9. Tabulasi Silang Berdasarkan Kepribadian

\begin{tabular}{|c|c|c|c|c|c|c|}
\hline Kepribadian & Jumlah & Mean & Std.Deviation & Zhitung & Ztabel & Kesimpulan \\
\hline Introvert & 200 & 3.63 & 0.35 & \multirow{2}{*}{-2.24} & \multirow{2}{*}{1.96} & $\begin{array}{c}\text { Tidak } \\
\text { Signifikan }\end{array}$ \\
\hline Ekstrovert & 191 & 3.76 & 0.31 & & & \\
\hline
\end{tabular}

Sumber: Analisis Peneliti (2021)

Berdasarkan tabel 9 hasil tabulasi silang pada variabel work engagement untuk kepribadian $\mathrm{Z}$ hitung dengan nilai $-2,24<Z$ tabel sejumlah 1,96. Dapat disimpulkan Ho diterima, maka work engagement tenaga kesehatan berdasarkan kepribadian tidak ada perbedaan.

- Berdasarkan Kebiasaan Makan Bubur

Tabel 10. Tabulasi Silang Berdasarkan Kebiasaan Makan Bubur

\begin{tabular}{|c|c|c|c|c|c|c|}
\hline $\begin{array}{c}\text { Kebiasaan Makan } \\
\text { Bubur }\end{array}$ & Jumlah & Mean & Std.Deviation & Zhitung & Ztabel & Kesimpulan \\
\hline Tim Bubur Diaduk & 189 & 3.64 & 0.56 & -1.72 & 1.96 & $\begin{array}{c}\text { Tidak } \\
\text { Signifikan }\end{array}$ \\
\hline $\begin{array}{c}\text { Non-Tim Bubur } \\
\text { Diaduk }\end{array}$ & 202 & 3.74 & 0.6 & -1.72 \\
\hline
\end{tabular}

Sumber: Analisis Peneliti (2021)

Berdasarkan tabel 10 hasil tabulasi silang pada variabel work engagement untuk kebiasaan makan bubur memperoleh $\mathrm{Z}$ hitung $(-1,72)<\mathrm{Z}$ tabel $(1,96)$, Ho diterima. Maka work engagement tenaga kesehatan berdasarkan kebiasaan makan bubur tidak ada perbedaan.

\subsection{Uji Hipotesis}

- Koefisien Determinasi

Tabel 11. Koefisien Determinasi 1

\begin{tabular}{|l|r|l|l|l|}
\hline \multicolumn{5}{|c|}{ Model Summary } \\
\hline Model & R & R Square & $\begin{array}{l}\text { Adjusted } \\
\text { R Square }\end{array}$ & $\begin{array}{l}\text { Std. Error of } \\
\text { the Estimate }\end{array}$ \\
\hline 1 & $.704^{\mathrm{a}}$ & 0.495 & 0.492 & 5.39257 \\
\hline
\end{tabular}

a. Predictors: (Constant), Digital Quotient (X1), Authentic Leadership (X2), Perceived Organizational Support (X3) 
Dapat dilihat pada tabel jika nilai R Square dengan nilai 0,495 atau $49,5 \%$ work engagement bisa diuraikan melalui variabel bebas yaitu digital quotient, authentic leadership dan perceived organizational support. Sedangkan 50,5\% sisanya diuraikan pada variabel lainnya.

Tabel 12. Koefisien Determinasi 2

\begin{tabular}{|c|c|c|c|c|}
\hline \multicolumn{5}{|c|}{ Model Summary } \\
\hline Model & $\mathrm{R}$ & R Square & $\begin{array}{l}\text { Adjusted R } \\
\text { Square }\end{array}$ & $\begin{array}{l}\text { Std. Error of } \\
\text { the Estimate }\end{array}$ \\
\hline 1 & $.612^{\mathrm{a}}$ & 0.375 & 0.372 & 9.32851 \\
\hline
\end{tabular}

Sumber: Analisis Peneliti (2021)

a. Predictors: (Constant), Authentic Leadership (X2), Perceived Organizational Support (X3)

Pada Tabel 12 didapatkan nilai $\mathrm{R}$ Square sebesar 0,375 atau sama dengan 37,5\% digital quotient dapat diketahui melalui variabel bebasnya yaitu, authentic leadership dan perceived organizational support. Sementara $62,5 \%$ sisanya diketahui oleh variabel lainnya.

Tabel 13. Koefisien Determinasi 3

\begin{tabular}{|l|l|l|l|l|}
\hline \multicolumn{4}{|l|}{ Model Summary } \\
\hline Model & R & R Square & $\begin{array}{l}\text { Adjusted } \\
\text { R Square }\end{array}$ & $\begin{array}{l}\text { Std. Error of } \\
\text { the Estimate }\end{array}$ \\
\hline 1 & $.787^{\mathrm{a}}$ & 0.619 & 0.618 & 4.79186 \\
\hline
\end{tabular}

Sumber: Analisis Peneliti (2021)

a. Predictors: (Constant), Percieved Organizational Support (X3)

Tabel 13 menunjukkan nilai R Square sebesar 0,619 (61,9\%) authentic leadership dapat dijelaskan melalui variabel bebasnya yaitu perceived organizational support. Sementara sisanya sebesar $38,1 \%$ dijelaskan oleh variabel lainnya.

- $\quad$ Uji T

Tabel 14. Hasil Uji T

\begin{tabular}{|l|l|c|c|c|}
\hline \multicolumn{1}{|c|}{ Variabel Terikat } & \multicolumn{1}{|c|}{ Variabel Bebas } & T Hitung & Sig T & Keterangan \\
\hline Work Engagement $(Y)$ & Digital Quotient (X1) & 9,053 & 0,000 & Signifikan \\
\hline Work Engagement $(Y)$ & Authentic Leadership (X2) & 2,244 & 0,025 & Signifikan \\
\hline Work Engagement (Y) & $\begin{array}{l}\text { Perceived Organizational } \\
\text { Support (X3) }\end{array}$ & 4,284 & 0,000 & Signifikan \\
\hline Digital Quotient (X1) & Authentic Leadership (X2) & 6,233 & 0,000 & Signifikan \\
\hline Digital Quotient (X1) & $\begin{array}{l}\text { Perceived Organizational } \\
\text { Support (X3) }\end{array}$ & 3,685 & 0,000 & Signifikan \\
\hline $\begin{array}{l}\text { Authentic Leadership } \\
(\mathrm{X} 2)\end{array}$ & $\begin{array}{l}\text { Perceived Organizational } \\
\text { Support (X3) }\end{array}$ & 25,144 & 0,000 & Signifikan \\
\hline
\end{tabular}

Sumber: Analisis Peneliti (2021)

Berdasarkan keputusan pada uji $\mathrm{T}$ mendapatkan hasil, Adanya pengaruh signifikan antara digital quotient terhadap work engagement, terdapat pengaruh signifikan antara authentic leadership dengan work engagement, perceived organizational support dengan work engagement berpengaruh signifikan, ada pengaruh signifikan pada authentic leadership dan digital quotient, perceived organizational support dan digital quotient berpengaruh secara signifikan, serta terdapat pengaruh antara perceived organizational support dengan authentic leadership dengan signifikan pada tenaga kesehatan di Jakarta Barat. 
- Regresi Linear Berganda

Tabel 15. Hasil Analisis Regresi Berganda Persamaan 1

\begin{tabular}{|c|c|c|c|c|c|c|}
\hline \multicolumn{7}{|c|}{ Coefficients $^{\mathrm{a}}$} \\
\hline & & \multicolumn{2}{|c|}{$\begin{array}{l}\text { Unstandardized } \\
\text { Coefficients }\end{array}$} & \multirow{2}{*}{$\begin{array}{l}\text { Standardized } \\
\text { Coefficients } \\
\text { Beta }\end{array}$} & \multirow[b]{2}{*}{$\mathrm{t}$} & \multirow[b]{2}{*}{ Sig. } \\
\hline \multicolumn{2}{|c|}{ Model } & B & Std. Error & & & \\
\hline 1 & (Constant) & 8.628 & 2.094 & & 4.119 & 0.000 \\
\hline & $\begin{array}{l}\text { Digital Quotient } \\
\text { (X1) }\end{array}$ & 0.266 & 0.029 & 0.413 & 9.053 & 0.000 \\
\hline & $\begin{array}{l}\text { Authentic } \\
\text { Leadership } \\
\text { (X2) }\end{array}$ & 0.134 & 0.060 & 0.138 & 2.244 & 0.025 \\
\hline & $\begin{array}{l}\text { Perceived } \\
\text { Organizational } \\
\text { Support } \\
\text { (X3) }\end{array}$ & 0.232 & 0.054 & 0.255 & 4.284 & 0.000 \\
\hline
\end{tabular}

a. Dependent Variable: Work Engagement (Y)

Sumber: Analisis Peneliti (2021)

Berdasarkan table 15 didapatkan persamaan regresi sebagai berikut: Work engagement $=8,628+0,413$ (digital quotient) $+0,138$ (authentic leadership) $+0,255$ (perceived organizational support). Jika digital quotient, authentic leadership, dan perceived organizational support mengalami kenaikan sebesar 1 satuan maka work engagement akan mengalami kenaikan sebesar 0,806. Apabila work engagement penurunan sebesar 1 satuan, maka work engagement akan mengalami penurunan sebesar 0,806 . Bila digital quotient, authentic leadership, dan perceived organizational support bernilai 0 , maka variabel work engagement akan bernilai sebesar 8,628.

Tabel 16. Hasil Analisis Regresi Berganda Persamaan 2

\begin{tabular}{|c|c|c|c|c|c|c|}
\hline \multicolumn{7}{|c|}{ Coefficients $^{\mathrm{a}}$} \\
\hline \multirow{2}{*}{\multicolumn{2}{|c|}{ Model }} & \multicolumn{2}{|c|}{$\begin{array}{l}\text { Unstandardized } \\
\text { Coefficients }\end{array}$} & \multirow{2}{*}{$\begin{array}{l}\text { Standardized } \\
\text { Coefficients } \\
\text { Beta } \\
\end{array}$} & \multirow{3}{*}{$\frac{\mathrm{t}}{16.785}$} & \multirow{3}{*}{$\frac{\text { Sig. }}{0.000}$} \\
\hline & & \multirow{2}{*}{$\frac{B}{46.287}$} & \multirow{2}{*}{$\begin{array}{l}\text { Std. Error } \\
2.758\end{array}$} & & & \\
\hline 1 & (Constant) & & & & & \\
\hline & $\begin{array}{l}\text { Authentic } \\
\text { Leadership } \\
\text { (X2) }\end{array}$ & 0.615 & 0.099 & 0.405 & 6.233 & 0.000 \\
\hline & $\begin{array}{l}\text { Perceived } \\
\text { Organizational } \\
\text { Support } \\
\text { (X3) }\end{array}$ & 0.339 & 0.092 & 0.240 & 3.685 & 0.000 \\
\hline
\end{tabular}

a. Dependent Variable: Digital Quotient (X1)

Sumber: Analisis Peneliti (2021)

Berdasarkan table 16 didapatkan persamaan regresi sebagai berikut: Digital quotient $=46,287+0,405$ (authentic leadership) + 0,240 (perceived organizational support). Jika authentic leadership dan perceived organizational support mengalami kenaikan sebesar 1 satuan, maka digital quotient akan 
mengalami kenaikan sebesar 0,645. Apabila authentic leadership dan perceived organizational support mengalami penurunan sebesar 1 satuan, maka digital quotient akan mengalami penurunan sebesar 0,645. Ketika authentic leadership dan perceived organizational support bernilai 0, maka digital quotient akan bernilai sebesar 46,287.

Tabel 17 Hasil Analisis Regresi Sederhana Persamaan 3

\begin{tabular}{|c|c|c|c|c|c|c|}
\hline \multicolumn{7}{|c|}{ Coefficients $^{a}$} \\
\hline \multirow{2}{*}{\multicolumn{2}{|c|}{ Model }} & \multicolumn{2}{|c|}{$\begin{array}{l}\text { Unstandardized } \\
\text { Coefficients }\end{array}$} & \multirow{2}{*}{$\begin{array}{l}\text { Standardized } \\
\text { Coefficients }\end{array}$} & \multirow[b]{2}{*}{$\mathrm{t}$} & \multirow[b]{2}{*}{ Sig. } \\
\hline & & B & Std. Error & & & \\
\hline 1 & (Constant) & 6.721 & 1.375 & & 4.888 & 0.000 \\
\hline & $\begin{array}{l}\text { Perceived } \\
\text { Organizational } \\
\text { Support } \\
\text { (X3) }\end{array}$ & 0.733 & 0.029 & 0.787 & 25.144 & 0.000 \\
\hline
\end{tabular}

a. Dependent Variable: Authentic Leadership (X2)

Sumber: Analisis Peneliti (2021)

Berdasarkan table 17 didapatkan persamaan regresi sebagai berikut: Authentic leadership $=6,721+$ 0,787 (perceived organizational support). Saat perceived organizational support mengalami kenaikan sebesar 1 satuan, maka authentic leadership akan mengalami kenaikan sebesar 0,787. Apabila perceived organizational support mengalami penurunan sebesar 1 satuan, maka variabel authentic leadership akan mengalami penurunan sebesar 0,787. Maka perceived organizational support bernilai 0, maka authentic leadership akan bernilai sebesar 6,721.

\subsection{Implikasi Hasil Penelitian}

- Implikasi Praktis

Apabila tenaga kesehatan memiliki tingkat work engagement yang lebih tinggi maka tenaga kesehatan akan merasa terlekat dengan pekerjaannya karena mereka lebih termotivasi dan lebih fokus dalam menjalankan pekerjaannya. Dalam kondisi tersebut juga akan meningkatkan performa kinerja yang lebih tinggi untuk mendorong pencapaian perusahaan. Dengan demikian, untuk dapat meningkatkan work engagement perusahaan dituntut untuk dapat memberikan perhatian dalam digital quotient tenaga kesehatan. Digital quotient membutuhkan perhatian dari perusahaan agar tenaga kesehatan dapat memanfaatkannya secara positif dan benar. Dalam dunia digital juga banyak terjadi kejahatan seperti peretasan, pencurian data pribadi, pelanggaran privasi hingga penyebaran informasi palsu yang tidak faktual. Perhatian tersebut juga dilakukan untuk menekan dampak negatif yang dapat mengarah kepada penggunaan media digital yang berlebihan saat jam kerja yang dapat mengganggu konsentrasi dan performa kinerja. Berdasarkan hasil penelitian diperoleh hasil bahwa digital quotient tenaga kesehatan di Jakarta Barat telah memiliki nilai yang tinggi namun masih ada bagian yang dapat diperhatikan agar dapat meningkatkan work engagement. Perhatian yang diberikan kepada tenaga kesehatan di Jakarta Barat juga tidak lepas dari tingkat authentic leadership dari perusahaan yang tinggi. Pemimpin yang dapat mendengarkan pendapat orang lain merupakan pemimpin yang turut berperan dalam performa kinerja tenaga kesehatan. Selain authentic leadership, berdasarkan dari hasil penelitian perceived organizational support juga memiliki tingkat yang tinggi. Dengan mendapatkan dukungan dari perusahaan seperti menghargai dan merasa bangga dengan kesuksesan tenaga kesehatan dapat membawa dampak yang besar dalam mencapai kesuksesan bersama. 


\section{- Implikasi Teoritis}

Hasil penelitian menunjukkan bahwa digital quotient, authentic leadership dan perceived organizational support memiliki pengaruh signifikan terhadap work engagement pada tenaga kesehatan di Jakarta Barat sehingga perusahaan harus dapat mempertahankannya. Berdasarkan hasil penelitian yang diolah dengan SPSS dapat diketahui bahwa digital quotient berpengaruh signifikan terhadap work engagement. Hal juga sesuai dengan penelitian Fitaloka et al. (2020) dengan judul "Leadership Agility and Digital Quotient Influence on Employee Engagement: A Case of PT X and Pinrumah.com" yang menyatakan bahwa digital quotient berpengaruh secara signifikan terhadap employee engagement. Hasil penelitian memiliki nilai sig digital quotient sebesar $0,000<0,05$ sehingga menyimpulkan digital quotient memiliki pengaruh positif terhadap employee engagement. Hal ini juga didukung dengan penelitian yang telah dilakukan oleh Prahara et al (2020) dengan judul "The Millennials: Adversity Intelligence and Work Engagement" yang menyatakan terdapat hubungan positif yang sangat signifikan antara adversity intelligence dan work engagement pada karyawan milenial yang tinggal di Yogyakarta. Pada penelitian tersebut memiliki nilai $(\mathrm{R})$ sebesar $0,820(\mathrm{p}<0,01)$.

Hasil penelitian authentic leadership memiliki pengaruh signifikan terhadap work engagement. Penelitian Samsudin et al. (2020) dengan judul "Authentic Leadership, Work Engagement and Performance: Looking into a Healthcare Faith-Based Organization" menyatakan authentic leadership berpengaruh secara signifikan terhadap work engagement. Karena pada penelitian tersebut, t hitung memiliki skor 7,375 yang lebih besar dari 1,96 atau sig 0,00<0,05. Kemudian di hasil penelitian Plessis dan Boshoff (2018) yang berjudul "The role of psychological capital in the relationship between authentic leadership and work engagement." menyimpulkan bahwa authentic leadership tidak berpengaruh signifikan terhadap work engagement dimana hasil penelitian tersebut t hitung 2,467 yang lebih kecil dari 3,410 atau sig 0,007 yang lebih kecil dari 0,05. Pada penelitian Álvarez et al. (2019) yang berjudul "Authentic leadership and its relationships with work engagement and organizational citizenship behaviors in military units: The role of identification as a mediating variable" menujukkan bahwa terdapat pengaruh positif dengan work engagement dengan koesfisien determinasi 0,19 dan ( $p$ $<0,01)$ atau nilai alpha yang lebih kecil nilai 0,01 .

Hasil penelitian yang diolah oleh SPSS didapatkan hasil bahwa authentic leadership berpengaruh signifikan terhadap digital quotient. Pada penelitian Miao et al (2018) berjudul "Emotional intelligence and authentic leadership: a meta-analysis" mengatakan bahwa terdapat pengaruh antara emotional intelligence dan authentic leadership dengan nilai interval kepercayaan sebesar $95 \%$ berkisar antara 0,35 hingga 0,64 dan ini tidak termasuk nol (0).

Penelitian yang diolah dengan SPSS mendapatkan hasil dengan kesimpulan bahwa perceived organizational support menujukkan pengaruh yang signifikan kepada work engagement. Penelitian Stefanidis dan Strogilos (2021) dengan judul "Perceived organizational support and work engagement of employees with children with disabilities" memiliki hasil supervisor's support berpengaruh signifikan dengan work engagement dengan hasil penelitian tersebut memiliki nilai sig yang lebih kecil dari 0,01. Begitu juga dengan penelitian Imran et al (2020) "Impact of Perceived Organizational Support on Work Engagement: Mediating Mechanism of Thriving and Flourishing" memberikan hasil jika perceived organizational support dengan work engagement berpengaruh dengan beta 0,27 dan alpha lebih kecil dari 0,001 ( $\mathrm{p}<0,001)$.

Sesuai dengan hasil penelitian perceived organizational support berpengaruh signifikan kepada authentic leadership. Hasil penelitian Bilgetürk dan Baykal (2021) dengan judul "How does Perceived Organizational Support Affect Psychological Capital? The Mediating Role of Authentic Leadership" juga menyatakan bahwa perceived organizational support berpengaruh signifikan terhadap authentic leadership. Penelitian tersebut menyatakan kekuatan hubungan yang diperkirakan 0,892 dan menunjukkan hubungan signifikan yang kuat pada tingkat 0,001 . Untuk setiap kenaikan authentic leadership pada standar deviasi 1 maka perceived organizational support akan meningkat pada nilai 0,892. Begitu juga dengan penelitian Vermeulen dan Scheepers (2020) berjudul "Mediating effect of perceived organizational support on authentic leadership and work engagement" mengasilkan estimasi nilai 0,89207 menunjukkan pengaruh yang kuat pada perceived organizational support dan authentic 
leadership pada tingkat nilai signifikasi tingkat.

Hasil penelitian yang telah diolah menggunakan SPSS mendapatkan hasil bahwa perceived organizational support dan digital quotient memiliki pengaruh. Penelitian Rasouli et al (2019) dengan judul "Investigating the Relationship between Work-Family Conflict (WFC) and Organizational Intelligence with the Mediating Role of Perceived Organizational Support and Job Performance of Nurses in Golestan Hospital of Ahvaz City, Khuzestan, Iran" mendukung hasil penelitian dengan beta sebesar 0,289 dan nilai alpha sebesar 0,000 sehingga dapay disimpulkan bahwa terdapat hubungan positif antara organizational intelligence and perceived organizational support.

\section{Kesimpulan dan Saran}

Hasil penelitian yang telah dilakukan terhadap tenaga kesehatan di Jakarta Barat bisa mendapatkan kesimpulan bahwa (1) digital quotient terhadap work engagement memiliki pengaruh yang signifikan dan kuat, pengaruh yang terjadi adalah searah atau positif. Apabila digital quotient naik maka work engagement akan naik. (2) Pengaruh antara authentic leadership terhadap work engagement merupakan signifikan dan kuat, pengaruh yang terjadi yaitu searah atau positif. Apabila authentic leadership pemimpin di Jakarta Barat baik maka work engagement akan naik. (3) Terdapat hubungan antara authentic leadership terhadap digital quotient secara signifikan dan kuat, pengaruh yang terjadi adalah searah atau positif. Jika authentic leadership pemimpin di Jakarta Barat baik maka digital quotient akan naik. (4) Perceived organizational support terhadap work engagement yaitu signifikan dan kuat, pengaruh yang terjadi ialah searah atau positif. Jika perceived organizational support di Jakarta Barat baik maka work engagement akan naik. (5) Terdapat pengaruh antara perceived organizational support terhadap digital quotient yaitu signifikan dan kuat, pengaruh yang terjadi adalah searah atau positif. Apabila perceived organizational support pemimpin di Jakarta Barat baik maka digital quotient akan naik. (6) Pengaruh perceived organizational support terhadap digital quotient memiliki hasil signifikan dan kuat, pengaruh yang terjadi merupakan searah atau positif. Apabila perceived organizational support pemimpin di Jakarta Barat baik maka digital quotient akan naik.

Berdasarkan hasil kesimpulan di atas, maka saran yang bisa disampaikan untuk tenaga kesehatan di Jakarta Barat (1) Pada work engagement mendapatkan hasil penelitian yang membuktikan bahwa poin paling rendah ada pada pernyataan emosional dengan banyaknya pekerjaan membuat lelah. Meskipun tenaga kesehatan di Jakarta Barat merasa lelah, mereka bangga dengan pekerjaannya. Maka dari itu hendaknya tenaga kesehatan tetap mempertahankan rasa bangga terhadap pekerjaannya meskipun melelahkan. (2) hasil penelitian tentang digital quotient menunjukan bahwa tenaga kesehatan selalu memakai password pada social media. Hal ini perlu dipertahankan karena untuk menjaga keamanan social media agar terhindar dari peretasan, penipuan dan hal yang tidak diinginkan. (3) hasil penelitian tentang authentic leadership menunjukkan bahwa tenaga kesehatan memiliki pemimpin yang dapat mendengarkan pendapat orang lain dan menjadi dirinya sendiri. Hal ini harus dipertahankan agar tenaga kesehatan selalu positif dalam menjalankan pekerjaannya. (4) hasil penelitian tentang perceived organizational support menunjukan bahwa dukungan dan rasa bangga terhadap tenaga kesehatan dari perusahaan berperan penting dalam kesuksesan mereka. Maka dari itu perusahaan perlu mempertahankan perhatiannya kepada tenaga kesehatan agar mereka dapat mencapai kesuksesan.

\section{Limitasi dan Studi Lanjutan}

Penelitian dibatasi oleh variabel work engagement, digital quotient, authentic leadership, dan perceived organizational support. Objek penelitian juga dibatasi oleh tenaga kesehatan yang bekerja di Jakarta Barat selama masa pandemi COVID - 19. Penulis mengalami sedikit hambatan dikarenakan masih terbatasnya literasi mengenai digital quotient, dan dalam mengumpulkan data responden namun peneliti dapat menyelesaikan pengumpulan data responden dan juga menyelesaikan penelitian. Di tengah pandemi ini memaksa tenaga kesehatan untuk tetap membantu saudara/i kita di Rumah Sakit, sehingga mempengaruhi jawaban atas perceived organizational support karena mereka dituntut untuk lebih menjaga perlindungan diri dan lebih termotivasi saat kerja karena merasa diperhatikan selama masa pandemi. Untuk kedepan penulis akan meninjau faktor lainnya untuk diteliti dengan kemungkinan 
memiliki pengaruh terhadap work engagement dan wilayan penelitian akan dikembangkan menjadi lebih luas.

\section{Ucapan Terima Kasih}

Penulis ingin menyampaikan ucapan terimakasih yang sebesar-besarnya kepada Tuhan Yang Maha Esa, orang tua penulis yang memberikan dukungan finansial dan non-finansial, Pak Nopriadi Saputra sebagai dosen pembimbing, teman-teman penulis, dan Universitas Bina Nusantara yang telah memberikan bantuan dan dukungan kepada penulis baik secara langsung maupun tidak langsung, yang membuat penulis dapat menyelesaikan penelitian ini hingga selesai.

\section{Referensi}

Alavi, S. B., \& Gill, C. (2017). Leading Change Authentically: How Authentic Leaders Influence Follower Responses to Complex Change. Journal of Leadership and Organizational Studies, 24(2), 157-171. https://doi.org/10.1177/1548051816664681

Bartlett-Bragg, A. (2017). Digital Capabilities: Where People and Technology Intersect. EDULEARN17 Proceedings, 1(July), 14-21. https://doi.org/10.21125/edulearn.2017.1004

Bilgetürk, M., \& Baykal, E. (2021). How does perceived organizational support affect psychological capital? The mediating role of authentic leadership. Organizacija, 54(1).

Caza, A., \& Jackson, B. (2011). Authentic leadership. The SAGE handbook of leadership, 352-364.

Datta, B., \& Gupta, V. (2015). Assessing the Effectiveness of Authentic Leadership. International Journal of Leadership Studies, 9(1).

du Plessis, M., \& Boshoff, A. B. (2018). Authentic leadership, followership, and psychological capital as antecedents of work engagement. Journal of Psychology in Africa, 28(1), 26-32. https://doi.org/10.1080/14330237.2018.1438832

Eisenberger, R., Armeli, S., Rexwinkel, B., Lynch, P. D., \& Rhoades, L. (2001). Reciprocation of POS. In Journal of Applied Psychology (Vol. 86, Issue 1, pp. 42-51).

Fitaloka, R., Sugarai, B., Arung Perkasa, A. R., \& Saputra, N. (2020). Leadership Agility and Digital Quotient Influence on Employee Engagement: between PT.X and PINRUMAH.COM. The Winners, 21(2), 113-117. https://doi.org/10.21512/tw.v21i2.6768

Ghozali, Imam. 2018. Aplikasi Analisis Multivariate dengan Program IBM SPSS 25. Badan Penerbit Universitas Diponegoro: Semarang.

Hakanen, J. J., Ropponen, A., Schaufeli, W. B., \& De Witte, H. (2019). Who is Engaged at Work?: A Large-Scale Study in 30 European Countries. Journal of Occupational and Environmental Medicine, 61(5), 373-381. https://doi.org/10.1097/JOM.0000000000001528

Imran, M. Y., Elahi, N. S., Abid, G., Ashfaq, F., \& Ilyas, S. (2020). Impact of perceived organizational support on work engagement: Mediating mechanism of thriving and flourishing. Journal of Open Innovation: Technology, Market, and Complexity, 6(3), 82.

Iswanto, F., \& Agustina, I. (2017). Peran dukungan sosial di tempat kerja terhadap keterikatan kerja karyawan. Mediapsi, 2(2), 38-45.

Kompas. (2021). Kasus Covid-19 di Jakarta Barat Melonjak Dua Kali Lipat 2 Pekan Terakhir. Diakses pada 22 Januari 2021, dari https://megapolitan.kompas.com/read/2021/01/20/12085381/kasuscovid-19-di-jakarta-barat-melonjak-dua-kali-lipat-2-pekan-terakhir

Krejcie, R. V., \& Morgan, D. W. (1970). Determining Sample Size for Research Activities. Educational and Psychological Measurement, 30(3), 607-610. https://doi.org/10.1177/001316447003000308

Kuncoro, M. (2013). Metode Riset Untuk Bisnis dan Ekonomi. Erlangga: Jakarta.

Kawalcovid. (2021). Kawal informasi seputar COVID-19 secara tepat dan akurat. Diakses pada 22 Januari 2021, dari https://kawalcovid19.id/

Joo, B. K., \& Jo, S. J. (2017). The effects of perceived authentic leadership and core self-evaluations on organizational citizenship behavior. Leadership \& Organization Development Journal

Laporcovid. (2021). Tenaga Kesehatan Indonesia yang tercatat gugur melawam Covid-19. Diakses pada 14 Maret 2021, dari https://nakes.laporcovid19.org/

Lee, J. Y., Rocco, T. S., \& Shuck, B. (2020). What Is a Resource: Toward a Taxonomy of Resources for Employee Engagement. Human Resource Development Review, 19(1), 5-38. https://doi.org/10.1177/1534484319853100 
Lind, Douglas A., Marchal, William G., Wathen, S. A. (2012). Statistical Techniques in Business \& Economics.

Macey, W. H., Schneider, B., \& Barbera, K. M. (2009). Employee Engagement: Competitive Advantage. 20-23.

Miao, C., Humphrey, R. H., \& Qian, S. (2018). Emotional intelligence and authentic leadership: a meta- analysis. Leadership \& Organization Development Journal.

Mujiasih, E. (2015). Hubungan Antara Persepsi Dukungan Organisasi (Perceived Organizational Support) Dengan Keterikatan Karyawan. Jurnal Psikologi Undip, 14(1), 40-51. https://doi.org/10.14710/jpu.14.1.40-51

Murthy, R. K. (2017). Perceived organizational support and work engagement. International Journal Applied Research, 3(5), 738-740.

Na-Nan, K., Roopleam, T., \& Wongsuwan, N. (2019). Validation of a digital intelligence quotient questionnaire for employee of small and medium-sized Thai enterprises using exploratory and confirmatory factor analysis. Kybernetes.

Oh, J., Cho, D., \& Lim, D. H. (2018). Authentic leadership and work engagement: the mediating effect of practicing core values. Leadership and Organization Development Journal, 39(2), 276-290. https://doi.org/10.1108/LODJ-02-2016-0030

Paat, Y. (2021). DKI Jakarta Laporkan Kasus Aktif Covid-19 Tertinggi pada 14 Mei 2021. Diakses pada 17 Mei 2021, dari https://www.beritasatu.com/megapolitan/789841/covid19-di-jakarta-ini25-kelurahan-dengan-kasus-tertinggi

PPNI. (2021). Perawat Manajer Berperan Dalam Peningkatan Pelayanan di RS. diakses pada 22 Januari 2021, dari https://www.ppni-inna.org/index.php/public/information/news-detail/349

Prahara, S. A., Dewi, R. P., \& Astuti, K. (2020). The millennials: Adversity intelligence and work engagement. Journal of Psychology and Instruction, 4(3), 71-76.

Rahmadi, D. (2020). Peran Tenaga Medis dan Media Sosial Dalam Memutus Rantai Penyebaran Covid-19. Diakses pada 30 April 2021, dari https://m.merdeka.com/peristiwa/peran-tenagamedis-dan-media-sosial-dalam-memutus-rantai-penyebaran-covid-19.html

Ramadhan, A \& Meirina, Z. (2020). Kemenkes: Deteksi dini penyakit tidak menular cegah kematian COVID-19. Diakses pada 26 November 2020, dari https://www.antaranews.com/berita/1772197/kemenkes-deteksi-dini-penyakit-tidak-menularcegah-kematian-covid-19\#mobile-src

Rasouli, N., Heidari, A., Naderi, F., \& Marashian, F. S. (2019). Investigating the Relationship between Work-Family Conflict (WFC) and Organizational Intelligence with the Mediating Role of Perceived Organizational Support and Job Performance of Nurses in Golestan Hospital of Ahvaz City, Khuzestan, Iran. Preventive Care in Nursing \& Midwifery Journal, 9(3), 1-9.

Sahyaja, C., \& Rao, S. (2018). New leadership in the digital era-a conceptual study on emotional dimensions in relation with intellectual dimensions. International Journal of Civil Engineering and Technology.-2018.-9 (1).-P, 738-747

Samsudin, A., Saputra, N., \& Abdinegoro, S. B. (2020). Authentic Leadership, Work Engagement and Performance. January. https://doi.org/10.2991/aebmr.k.201222.040le

Saputra, N., \& Sasmoko, S. B. A. (2018). The holistic work engagement: A study In indonesia oil palm industry. International Journal of Engineering \& Technology, 7(4.9), 1-7.

Schaufeli, W. B. (2013). What is engagement? Employee Engagement in Theory and Practice, 15-35. https://doi.org/10.4324/9780203076965

Sekaran, Uma dan Bougie, Roger. 2016. Research Methods For Business: A Skill Building Approach, 7th Edition. New Jersey: Wiley

Simon, S. S. (2011). The Essentials of Employee Engagement in Organizations. Journal of $\begin{array}{llll}\text { Contemporary Research in } & \text { Management, 63-72. }\end{array}$ http://search.proquest.com/docview/920826469?accountid=14620

Smulders, P. (2006). De bevlogenheid van werknemers gemeten [Assessing employee's work engagement]. Hoofddorp: TNO-special september 2006.

Stefanidis, A., \& Strogilos, V. (2021). Perceived organizational support and work engagement of employees with children with disabilities. Personnel Review, 50(1), 186-206. https://doi.org/10.1108/PR-02-2019-0057

Sugiyono. (2017). Metode Penelitian Kuantitatif, Kualitatif, dan R\&D. Bandung : Alfabeta, CV. 
Theresia Waileruny, H. (2014). Perceived Organizational Support, Job Satistaction Dan Organizational Citizenship Behavior Pada PT. Bank Maluku Cabang Utama Kota Ambon. Agora, 2(2), 1-9. https://www.neliti.com/publications/35954/

Tims, M., Bakker, A. B., \& Xanthopoulou, D. (2011). Do transformational leaders enhance their followers' daily work engagement? Leadership Quarterly, 22(1), 121-131. https://doi.org/10.1016/j.leaqua.2010.12.011

Vermeulen, T., \& Scheepers, C. B. (2020). Mediating effect of perceived organisational support on authentic leadership and work engagement. SA Journal of Human Resource Management, 18, 12.

Walumbwa, F. O., Avolio, B. J., Gardner, W. L., Wernsing, T. S., \& Peterson, S. J. (2008). Authentic leadership: Development and validation of a theory-based measure. Journal of Management, 34(1), 89-126. https://doi.org/10.1177/0149206307308913. 